\title{
Analisis Implementasi Metode Jigsaw dalam Peningkatan Motivasi Belajar Siswa pada Mata Pelajaran Fikih Kelas VIII di MTS The Noor Pacet-Mojokerto
}

\author{
Aniatus Sholehah \\ aniatussholehah@gmail.com
}

Fakultas Tarbiyah Institut Pesantren Kh. Abdul Chalim Pacet Mojokerto, Indonesia

Fina Surya Anggraini

Fakultas Tarbiyah Institut Pesantren Kh. Abdul Chalim Pacet Mojokerto, Indonesia

\author{
Muhammad Husnur Rofiq \\ umasoviq@gmail.com
}

Fakultas Tarbiyah Institut Pesantren Kh. Abdul Chalim Pacet Mojokerto, Indonesia

\section{Abstract}

Learning activities involve several components for the success of teaching and learning and one of them is by applying effective learning methods which will provide a thorough understanding to students. The research focuses on: (1) How to Implement the Jigsaw Method in Increasing Learning Motivation in Fiqh Lessons Subjects Class VIII, and (2) How to Evaluate the Jigsaw Method in Improving Learning Motivation in Class VIII Fiqh Lessons. The findings in this study is the implementation of the Jigsaw Method in Increasing Students' Learning Motivation in Fiqh Lessons Subjects for Class VIII, the stages are: (a) Giving introduction material, (b) Formation of groups origin, (c) formation of expert groups, (d) Giving different materials/discussion of sub-materials, (e) presentation) Research findings on increasing participants' learning motivation VIII grade students at Madrasah tsanawiyah The Noor, namely : (a) Able to grow and improve students' learning enthusiasm, (b) Able to cultivate an unyielding or tenacious spirit, and responsibility, (c) Improve learning effectiveness, and (d) Able to improve student's learning outcomes.

Keywords: Jigsaw Method, Learning Motivation, Fiqh Subject.

\section{Pendahuluan}

Pendidikan menjadi sebuah kebutuhan sepanjang hidup bagi setiap individu yang kemudian akan memberikan suatu pengalaman belajar. Pendidikan akan mempengaruhi pertumbuhan individu menuju kearah pribadi yang lebih baik lagi ${ }^{1}$. Pendidikan juga dirasa sangat penting sebab mampu meningkatkan segala

1 Yeni Ciptaningsih and Muhammad Husnur Rofiq, "Participatory Learning With Game Method For Learning Completeness In Islamic Religious Education," Fikroh: Jurnal Pemikiran dan Pendidikan Islam 15, no. 1 (January 29, 2022): 18-29. 
pengetahuan. Peran guru dalam dunia pendidikan menduduki posisi terpenting bagi jalannya pendidikan terlebih lagi dianggap sangat strategis dalam dunia pendidikan. Bahwasanya mampu dikatakan berhasil tidaknya suatu pendidikan tergantung dari bagaimana guru dalam sebuah proses mengajar. ${ }^{2}$

Dalam dunia pendidikan akan terjadi suatu proses pembelajaran yang melibatkan interaksi guru dan para peserta didik beserta lingkungannya. Pembelajaran berkaitan dengan bagaimana para peserta didik terdorong untuk belajar dengan kemauannya sendiri untuk mempelajari apa seperti yang tercantum di dalam kurikulum yang berposisi sebagai kebutuhan para peserta didik. $^{3}$

Kegiatan pembelajaran sendiri akan melibatkan beberapa komponen bagi keberhasilan belajar-mengajar dan salah satunya adalah dengan menerapkan metode pembelajaran yang nantinya akan memberikan pemahaman menyeluruh kepada para peserta didik. ${ }^{4}$ Metode pembelajaran adalah komponen pembelajaran yang digunakan para guru dalam berlangsungnya proses belajar mengajar yang kemudian diharapkan para peserta didik dapat mencapai tujuan pembelajaran seperti yang telah dicantumkan dalam kurikulum, silabus serta mata pelajaran. ${ }^{5}$

Ragam metode pembelajaran menjadi senjata yang harus dikuasai oleh guru yang sesuai dengan siswa dan karakteristik dari materi yang akan diajarkan. ${ }^{6}$ Salah satu metode yang dirasa efektif serta inovatif untuk diterapkan dalam keberlangsungan proses pembelajaran guna meningkatkan pemahaman, kreatifitas serta memotivasi peserta didik dalam pembelajaran ialah dengan penerapan metode jigsaw di mana peserta didik lebih aktif dan guru berperan sebagai fasilitator, menjembatani proses pembelajaran.

Metode jigsaw ini terbilang baik dan tentunya cocok jika akan diterapkan dalam sebuah pembelajaran. Karena melalui penerapan metode ini para peserta didik jauh akan lebih mandiri dalam kegiatan belajarnya, yang artinya dalam hal ini peserta didik diberikan sebuah tanggung jawab untuk memecahkan materi yang diberikan kepadanya secara individu yang kemudian akan diselesaikan melalui kegiatan belajar antar sesama teman.

Penelitian yang dilakukan kali ini bertujuan: 1) Mengetahui pelaksanaan metode jigsaw dalam pembelajaran fikih kelas VIII di Madrasah Tsanawiyah The Noor Pacet-Mojokerto, serta 2) Menganalisis implikasi metode jigsaw dalam

2 Dinda Zulaikhah, Akhmad Sirojuddin, and Andika Aprilianto, "Analisis Pembelajaran Pendidikan Agama Islam Kurikulum 2013 Bagi Anak Berkebutuhan Khusus," Tafkir: Interdisciplinary Journal of Islamic Education 1, no. 1 (2020): 54-71.

${ }^{3}$ Nur Ainun Lubis and Hasrul Harahap, "Pembelajaran Kooperatif Tipe Jigsaw | Jurnal AsSalam," Jurnal As-Salam 1, no. 1 (2016), accessed January 31, 2022, https://jurnalassalam.org/index.php/JAS/article/view/48.

${ }^{4}$ Ali Muhdlorul Huda and Mauhibur Rokhman, "The Strategy of the Principal in Improving the Quality of Institutional Education," Attadrib: Jurnal Pendidikan Guru Madrasah Ibtidaiyah 4, no. 2 (November 5, 2021): 72-80.

${ }^{5}$ Rahmat, Evaluasi Pembelajaran Pendidikan Agama Islam (Bening Pustaka, 2019).

${ }^{6}$ Muhtar Tajuddin and Imam Syafi'i, "Blended Learning Model of Ulumul Hadith Through Whatsapp Media," Nazhruna: Jurnal Pendidikan Islam 4, no. 2 (June 12, 2021): 162-179. 
meningkatkan motivasi belajar siswa pada mata pelajaran fikih kelas VIII di Madrasah Tsanawiyah The Noor Pacet-Mojokerto.

Ada beberapa penelitian yang telah dilakukan terkait dengan implementasi metode jigsaw. Seperti Kusmaniar menyimpulkan bahwa penerapan pembelajaran dengan memakai metode jigsaw dapat meningkatkan motivasi belajar siswa dengan ditandai meningkatnya minat, perhatian dan partisipasi siswa dalam proses pembelajaran yang memiliki implikasi terhadap suasana pembelajaran yang menjadi lebih bergairah dan menyenangkan dan peserta didik lebih termotivasi dalam proses pembelajaran. ${ }^{7}$

Di Kelas VIII Madrasah Tsanawiyah The Noor Pacet Mojokerto pada mata pelajaran fikih ini menggunakan metode jigsaw sebagai sebuah metode yang dianggap bisa menghidupkan serta mengaktifkan belajar peserta didik di dalam kelas. Metode pembelajaran yang diterapkan pada pembelajaran ini guna untuk mencapai sebuah kompetensi yang ditetapkan. Pada metode ini peserta didik akan dibentuk menjadi sebuah kelompok belajar, mereka akan mendiskusikan materi yang diberi untuk dipecahkan di dalam sebuah kelompok kecil. Terlebih lagi pada pelajaran fikih yang merupakan salah satu mata pelajaran yang wajib untuk dipahami secara menyeluruh dan mendalam bagi setiap peserta didik.

Pelajaran fikih adalah salah satu mata pelajaran Pendidikan Agama Islam yang diarahkan untuk menyiapkan peserta didik untuk mengenal, memahami, menghayati terutama dalam ibadah sehari-hari, yang kemudian menjadi dasar pedoman hidup (way of life) melalui kegiatan bimbingan, pengajaran, latihan, penggunaan pengalaman dan pembiasaan. ${ }^{8}$ Materi yang dipelajari pada mata pelajaran fiqih khususnya jenjang madrasah Tsanawiyah kelas VIII semester 1 berdasarkan kurikulum 2013 ialah ketentuan sujud syukur, puasa, ketentuan zakat, shadaqah, hibah dan hadiah, haji dan umrah, makanan serta minuman yang halal. ${ }^{9}$

Metode jigsaw ini juga dimaksudkan mengubah kebiasaan guru yang dulunya lebih otoriter, maka dengan penerapan metode ini peran guru menjadi fasilitator sehingga proses pembelajaran akan jauh lebih efektif. Sebab selama ini pada mata pelajaran PAI termasuk pada bidang fikih, pendidik hanya menggunakan metode ceramah, yang sifatnya satu arah atau teacher oriented.10

7 Kusmaniar, "Peningkatan Motivasi Belajar Siswa Melalui Model Pembelajaran Kooperatif Tipe Jigsaw," FITRA 4, no. 1 (August 10, 2018), accessed January 31, 2022, http://jurnal.staitapaktuan.ac.id/index.php/fitra/article/view/62.

8 Zaenudin Zaenudim, "Meningkatkan Hasil Belajar Siswa Pada Mata Pelajaran Fiqh Melalui Penerapan Strategi Bingo," Edukasia: Jurnal Penelitian Pendidikan Islam 10, no. 2 (September 27, 2015), January 31, 2022, https://journal.iainkudus.ac.id/index.php/Edukasia/article/view/796.

9 Siti Na'ilul Hidayah and Ashif Az-zafi, "The Role Of The Religious Laboratory In Improving Students 'Understanding Of Fiqh Lessons," Tafkir: Interdisciplinary Journal of Islamic Education 2, no. 2 (July 25, 2021): 157-174.

10 Poetri Leharia Pakpahan and Umi Habibah, "Manajemen Program Pengembangan Kurikulum PAI Dan Budi Pekerti Dalam Pembentukan Karakter Religius Siswa: Management of IRE Curriculum Development Program and Character in Forming Student's Religious Character," Tafkir: Interdisciplinary Journal of Islamic Education 2, no. 1 (January 10, 2021): 1-20. 
Kebanyakan peserta didik sangat mudah bosan dengan metode belajar ceramah, sebab mereka hanya mendengarkan penjelasan dari pendidik tanpa ada kegiatan yang menyenangkan, sehingga membuat mereka jadi mudah bosan dan mengantuk. ${ }^{11}$ Hal tersebut dikarenakan perhatian seorang manusia khususnya anak cukup terbatas. Dalam 60 menit perhatian seseorang untuk menyimak atau memperhatikan tidak bisa 100 persen. ${ }^{12}$

Oleh karenanya diperlukan metode lain yang dapat membuat peserta didik lebih termotivasi dan bersemangat dalam kegiatan belajarnya. Sehingga harapannya tujuan pembelajaran dapat tercapai secara maksimal. Maka dalam hal ini penulis tertarik meneliti terkait penerapan sebuah metode pembelajaran yang cukup inovatif dan mampu menjadikan peserta didik lebih bersemangat dalam belajarnya, serta tepat sehingga materi juga mudah dipahami secara mendalam dan akan selalu teringat bagi peserta didik. ${ }^{13}$ Dan sebuah metode yang dirasa dimasa sekarang yang terbilang masih jarang digunakan para guru dalam pembelajaran yakni dengan metode jigsaw ini.

\section{Metode Penelitian}

Dalam penelitian ini, peneliti menggunakan penelitian deskriptif kualiatif. Yang dimana pada penelitian deskriptif kualitatif ini, peneliti mengumpulkan sejumlah data-data yang ada di lapangan. Adapun pada penelitian ini peneliti lebih mengarah kepada jenis penelitian studi kasus/field research. Penelitian studi kasus dilakukan untuk menggali suatu fenomena atau kegiatan tertentu dalam satu waktu serta mengumpulkan informasi secara terinci dan mendalam dengan menggunakan berbagai prosedur pengumpulan data selama periode tertentu.

Harapannya dengan jenis penelitian studi kasus peneliti dapat mengetahui bagaimana Penerapan Metode Jigsaw dalam Peningkatkan Motivasi Belajar Pada Mata Pelajaran Fikih kelas VIII di Madrasah Tsanawiyah The Noor Pacet Mojokerto. Adapun untuk pengumpulan data, peneliti menggunakan teknik wawancara, observasi, dokumentasi. Peneliti dalam mengawali penelitin ini melakukan wawancara yang ditujukan kepada Kepala Sekolah Madrasah, Guru Mata Pelajaran Fikih dan sebagian siswi.

Peneliti dalam melakukan penelitian ini juga melakukan observasi/pengamatan secara langsung di lapangan terkait bagaimana pelaksanaan dari metode jigsaw pada mata pelajaran fikih. Data-data yang telah didapatkan selanjutnya akan melalui tahap keabsahan dengan teknik triangulasi. Triangulasi adalah teknik pemeriksaan keabsahan data dengan cara menyilangkan

11 Akhmad Sirojuddin, Andika Aprilianto, and Novela Elza Zahari, "Peran Kepala Sekolah Sebagai Supervisor Pendidikan Dalam Meningkatkan Profesionalisme Guru," Chalim Journal of Teaching and Learning (CJoTL) 1, no. 2 (2021): 159-168.

12 Husnul Khotimah, Asep Supena, and Nandang Hidayat, "Meningkatkan attensi belajar siswa kelas awal melalui media visual," Jurnal Pendidikan Anak 8, no. 1 (August 21, 2019): 17-28.

13 Ratih Ratih and Fauzi Muharom, "Tasamuh Based E-Module Developtment in The Fiqih Subject for 10th Grade Students in Islamic Senior High School," Nazhruna: Jurnal Pendidikan Islam 4, no. 3 (October 19, 2021): 531-546. 
atau membandingkan informasi yang diperoleh dari beberapa sumber sehingga diperoleh data yang absah. ${ }^{14}$

Terdapat tahapan-tahapan dalam mengolah dan menganalisis data yang dilakukan peneliti di antaranya: (1) melakukan serangkaian wawancara kepada narasumber terkait, (2) mereduksi data, (3) mendisplay data, (4) melakukan penarikan kesimpulan dari serangkaian data. ${ }^{15}$ Lembaga sekolah yang menjadi tempat penelitian kali ini ialah di Madrasah Tsanawiyah The Noor PacetMojokerto dan dalam penelitian kali ini, peneliti melibatkan Kepala Sekolah, Guru Mata Pelajaran dan beberapa siswa Madrasah Tsanawiyah The Noor PacetMojokerto.

\section{Hasil Penelitian dan Pembahasan}

Lembaga pendidikan Madrasah Tsanawiyah The Noor Pacet-Mojokerto MTs. Pesantren The Noor adalah suatu lembaga yang berdomisili di Jl KH. Nur Ali No.01 Pringwulung Bendunganjati. Berdirinya MTs. Pesantren The Noor dilatar belakangi oleh semakin banyaknya lulusan Sekolah Dasar atau Madrasah Ibtidaiyah santri pondok pesantren Sabilul Muttaqin yang membutuhkan pendidikan yang lebih tinggi, karena tuntutan masyarakat yang ingin meningkatkan pendidikan anaknya dengan pendidikan yang diperoleh sebelumnya. Kenyataan yang ada pada saat itu banyak sekolah lanjutan pertama khususnya Madrasah Tsanawiyah belum mampu menampung jumlah lulusan Madrasah Ibtidaiyah atau Sekolah Dasar.

Sekolah ini tidak kalah dengan lembaga swasta yang lainnya, dalam kaitannya dengan kegiatan belajar-mengajarnya di lembaga ini menerapkan ragam inovasi metode pembelajaran. Hal ini yang menjadi titik point pembeda dengan sekolah lainnya di mana masih banyak sekolah yang sampai sekarang masih menerapkan metode pembelajaran konvensional.

Berdasarkan pembahasan data, diperoleh hasil (1) Pelaksanaan Metode Jigsaw Dalam Pembelajaran Fikih Kelas VIII di Madrasah Tsanawiyah The Noor Pacet-Mojokerto, dan (2) Implikasi Metode Jigsaw Dalam Meningkatkan Motivasi Belajar Siswa Pada Mata Pelajaran Fikih Kelas VIII di Madrasah Tsanawiyah The Noor Pacet-Mojokerto. Hasil penelitian ini, dapat dipaparkan sebagai berikut:

\section{Pelaksanaan Metode Jigsaw Pada Pembelajaran Fikih Kelas VIII Di Madrasah Tsanawiyah The Noor Pacet Mojokerto.}

Adanya sebuah metode pembelajaran yang begitu beragam tentunya dengan harapan akan dapat membantu pendidik menyampaikan materi pelajaran secara efektif dan efisien, sehingga para peserta didik mendapatkan pemahaman yang utuh. Oleh karena sebuah metode tidak hanya sebagai sebuah konsep teori namun juga harus dipraktikkan dan dilaksanakan di dalam pembelajaran. Pelaksanaan sebuah pembelajaran diartikan sebagai suatu kegiatan yang berupaya untuk saling

\footnotetext{
${ }^{14}$ Lexy J. Moleong, Metodologi penelitian kualitatif (Remadja Karya, 1989).

15 Sugiyono, Metode penelitian pendidikan: (pendekatan kuantitatif, kualitatif dan $R \mathcal{E} D$ ) (Alfabeta,
} 2008). 
berinteraksi guna berbagi serta mengolah sejumlah informasi pengetahuan yang diberikan dari seorang guru kepada para peserta didiknya dengan harapan informasi pengetahuan yang didapatkan mampu bermanfaat bagi peserta didik dan dapat diterapkan di kehidupan sehari-harinya dan di kemudian hari nanti.

Pelaksanaan metode jigsaw dalam sebuah pembelajaran diawali dengan dibuatnya sebuah rencana pelaksanaan pembelajaran atau yang sering disingkat dengan RPP. Sebagai sebuah usaha nyata dengan objek manusia, maka proses pembelajaran harus disiapkan sebaik mungkin termasuk pada saat perencanaannya. Hal tersebut telah tertuang dalam Permendikbud Nomor 22 tahun 2016 disebutkan bahwa setiap pendidik pada satuan pendidikan berkewajiban menyusun RPP secara lengkap dan sistematis agar pembelajaran berlangsung secara interaktif, inspiratif, menyenangkan, menantang, efisien, memotivasi peserta didik untuk berpartisipasi aktif, serta memberikan ruang yang cukup bagi prakarsa, kreativitas, dan kemandirian sesuai dengan bakat, minat, dan perkembangan fisik serta psikologis peserta didik.

Pembuatan RPP dilakukan sendiri oleh guru MTs The Noor Pacet dengan menyesuaikan alokasi waktu, alat, media, serta khususnya situasi peserta didik. Hal tersebut sangat menjadi titik perhatian oleh segenap pendidik di MTs The Noor, bahwasanya memahami kriteria peserta didik sangat penting dengan demikian pembuatan RPP harus dilakukan sendiri agar sesuai dengan situasi kondisi dan kriteria peserta didik yang akan dihadapi. Hal tersebut sesuai dengan yang disampaikan oleh Mawardi bahwasanya pembuatan RPP sangat harus dilakukan secara mandiri oleh guru yang mengajar agar tepat dengan situasi yang akan ditemui saat mengajar di kelas. ${ }^{16}$

Metode jigsaw merupakan salah satu dari metode belajar yang bisa diaplikasikan pada setiap mata pelajaran. Pada Mts The Noor Pacet metode ini sering digunakan pada mata pelajaran fikih. Adapun pelaksanaan metode jigsaw sendiri pada pelajaran fikih ini dilakukan dengan tahapan antara lain : 1) Pemberian pengantar materi, 2) Pembentukan kelompok belajar asal, 3) Pembentukan kelompok ahli, 4) Belajar sub materi, 5) Presentasi.

Tahap pertama pemberian materi adalah dengan pemberian secara ringan, artinya materi diberikan oleh pendidik atau guru hanya sebagai pengantar atau memberikan gambaran umum, gunanya untuk membawa dan menggiring peserta didik agar dapat berfikir tentang sub topik materi yang harus ia pecahkan hari itu. Kemudian dilanjut tahap kedua yakni pembentukan kelompok belajar. Pada Mts The Noor, pembentukan kelompok belajar pada metode jigsaw biasa dilakukan dengan jumlah kecil pada masing-masing kelompok, yakni berisikan empat sampai lima orang tiap kelompoknya. Kelompok belajar tersebut juga dilakukan secara acak sehingga sifatnya heterogen. Dengan demikian bertujuan agar siswa yang kurang faham dapat bergabung ke dalam kelompok siswa yang faham. Kelompok ini dinamakan dengan kelompok asal.

16 Mawardi Mawardi, “Optimalisasi Kompetensi Guru Dalam Penyusunan Rencana Pelaksanaan Pembelajaran," JURNAL ILMIAH DIDAKTIKA: Media Ilmiah Pendidikan dan Pengajaran 20, no. 1 (August 1, 2019): 69-82. 
Selain kedua tahap tersebut, tahap selanjutnya adalah pembentukan kelompok baru yang dinamakan dengan kelompok ahli. Pembentukan kelompok ini adalah dengan memberikan nomor yang berbeda kepada setiap anggota dalam satu kelompok yang terbentuk di awal. Pada tahap ini setiap anak dalam satu kelompok akan mendapatkan nomor yang berbeda. Kemudian anak-anak diminta untuk berkumpul pada temannya yang mendapatkan nommor yang sama dengannya. Pada tahap ini, maka terbentuk kelompok kedua yang dinamakan dengan kelompok ahli.

Tahap keempat adalah belajar sub materi. Pendidik memberikan sub materi pada setiap kelompok ahli untuk dibahas sedalam mungkin berbekal dari buku pegangan dan juga guru sebagai fasilitator. Pada tahap ini diharapkan anak-anak dalam kelompok ahli dapat saling membantu temannya untuk memahami sub materi karena dari pemahaman disini nantilah yang harus mereka jelaskan kembali pada teman-teman dikelompok asal.

Tahap terakhir yakni presentasi. Pada tahap ini anak-anak kembali ke kelompok asal dan bertugas. Maksudnya, anak-anak yang telah belajar dengan mendalam pada kelompok ahli (kedua) tadi ia akan kembali berkumpul dengan kelompok asalnya. Dan ia bertanggung jawab untuk menjelaskan sub materi yang di dapatkan tadi. Dengan demikian maka dalam kelompok asal akan memiliki tanggung jawab untuk menjelaskan hasil belajarnya dengan kelompok ahli tadi. Pemahaman akan lebih merata dan lebih mudah untuk dicerna oleh peserta didik karena dijelaskan oleh temannya sendiri dalam kelompok kecil yang pastinya akan lebih intensif dan kondusif. ${ }^{17}$

Hasil penelitian pada sekolah MTs The Noor tersebut tidak lain sesuai dengan apa yang disampaikan oleh Rusman dalam 'Buku Model-model Pembelajaran terkait langkah-langkah jigsaw'. Dijelaskan bahwa langkah-langkah metode jigsaw adalah (1) Siswa dikelompokkan dengan anggota kurang lebih 4-5 orang, (2) Tiap orang dalam tim diberikan materi atau tugas yang berbeda, (3) Anggota dalam tim yang berbeda dengan penugasan yang sama membentuk kelompok baru (kelompok ahli), (4) Setelah kelompok ahli berdiskusi, tiap anggota kembali ke kelompok asal dan menjelaskan kepada anggota kelompok tentang sub bab yang mereka kuasai, (5) Tiap tim ahli mempresentasikan hasil diskusi, (6) Pembahasan, dan (7) Penutup. ${ }^{18}$

Meskipun pada hasil penelitian yang dilakukan penulis pada MTs The Noor (5 poin) melalui wawancara bersama kepala sekolahnyadaripada yang disampaikan Rusman lebih banyak (7 poin) akan tetapi tetap memenuhi atau mencakup keseluruhan langkah atau tahapan metode jigsaw sebagaimana yang disampaikan oleh Rusman. Dengan demikian dapat dikatakan bahwa pelaksanaan

17 Tri Adi Muslimin and Ari Kartiko, "Pengaruh Sarana Dan Prasarana Terhadap Mutu Pendidikan Di Madrasah Bertaraf Internasional Nurul Ummah Pacet Mojokerto," Munaddhomah: Jurnal Manajemen Pendidikan Islam 1, no. 2 (2020): 75-87.

18 Rusman, Model-Model Pembelajaran Mengembangkan Profesionalisme Guru (Raja Grafindo Persada, 2016). 
metode jigsaw pada materi fikih di MTs The Noor sesuai dengan teori yang ada yakni yang disampaikan oleh Rusman.

\section{Implikasi Metode Jigsaw Dalam Meningkatkan Motivasi Belajar Siswa Pada Mata Pelajaran Fikih Kelas VIII di Madrasah Tsanawiyah The Noor Pacet- Mojokerto.}

Implikasi dari sebuah pelaksanaan metode pembelajaran dapat diketahui melalui proses evaluasi secara tepat. Evaluasi pelaksanaan metode jigsaw di MTs The Noor untuk pelajaran fikih dilakukan dengan dua bentuk, yakni evaluasi dengan tes tertulis yang berbentuk essay serta evaluasi non tes berupa pengamatan sikap.

Evaluasi tes yang berupa tes tertulis essay diberikan menjelang pelajaran selesai, yakni ketika peserta didik selesai melakukan kegiatan berkelompok dengan metode jigsaw. Harapannya, setelah melalui serangkaian tahapan pembelajaran denga nmetode jigsaw, peserta didik dapat memahami materi yang dibuktikan dengan kemampuannya menjawab soal essay secara mandiri.

Adapun untuk evaluasi non tes berupa pengamatan sikap adalah dilakukan disaat pelajaran berlangsung. Berdasarkan hasil penelitian, pengamatan dilakukan pada saat pembelajaran berlangsung khususnya adalah saat tahapan peserta didik berdiskusi dengan kelompok ahli memecahkan sub materi yang diberikan dan pada saat peserta didik mempresentasikan hasil diskusinya pada kelompok asalnya.

Pengaplikasian metode jigsaw pada pelajaran fikih di MTs The Noor Pacet memberikan dampak atau implikasi yang cukup signifikan, diantaranya adalah tumbuhnya antusiasme peserta didik terhadap mata pelajaran fikih. Berdasarkan hasil wawancara dengan pendidik di MTs the Noor kebanyakan peserat didik mengalami malas dan kurang semangat apabila melakukan pembelajaran secara konvensional atau hanya satu arah (metode ceramah).

Namun menggunakan metode jigsaw mampu membuat anak menjadi bersemangat dalam belajar, apalagi masalah fikih yang memang sangat diperlukan dalam kehidupan. Hasil temuan ini ternyata sesuai dengan apa yang disampaikan oleh Emda. Emda menyebutkan bahwa, dampak bagi peserta didik dari adanya penerapan metode jigsaw ini ialah suasana pembelajaran lebih bergairah dan menyenangkan serta semangat belajarnya semakin tinggi. ${ }^{19}$

Selain itu, penerapan metode jigsaw pada peserta didik MTs The Noor juga menumbuhkan jiwa pantang menyerahnya anak-anak. Menurut pemaparan kepala sekolah yang juga mendidik peserta didik secara langsung di kelas, bahwa anak-anak menjadi lebih tidak putus asa terhadap materi yang awalnya dirasa sulit. Hal tersebut terjawab dengan wawancara bersama salah satu peserta didik bahwasanya mereka merasa memiliki tanggung jawab untuk menjelaskan materi pada kelompok asalnya. Karena jika mereka tidak paham dengan submateri yang harus dipelajari saat bersama kelompok ahli, maka mereka tidak akan bisa

19 Amna Emda, “Kedudukan Motivasi Belajar Siswa Dalam Pembelajaran," Lantanida Journal 5, no. 2 (2018): 172-182. 
menjelaskan materi tersebut pada teman-temannya di kelompok ahli, dan hal tersebut berdampak pada kepentingan orang lain.

Sehubungan dengan hal tersebut maka dapat disebutkan bahwa implikasi lain dari penerapan metode jigsaw pada MTs The Noor tidak hanya menumbuhkan semangat belajar peserta didik, akan tetapi juga menumbuhkan jiwa pantang menyerahnya dan tanggung jawab. Dengan metode jigsaw peserta didik menjadi memiliki dua kewajiban yakni mempelajari materi untuk dirinya sendiri dan mengajarkan kepada teman di kelompok asalnya. Demikian metode jigsaw ini memang mampu meningkatkan rasa tanggung jawab peserta didik sebagaimana yang juga diungkapkan oleh Ramli. Dalam penelitiannya Ramli menyebutkan metode jigsaw merupakan tipe pembelajaran kooperatif, semua peserta didik saling tergantung satu sama lain dan harus bekerja sama secara kooperatif untuk emmpelajari materi yang ditugaskan. ${ }^{20}$

Hal tersebut juga sesuai dengan apa yang disampaikan oleh Emda, bahwasanya metode jigsaw tidak hanya mampu membuat suasana pembelajaran lebih bergairah dan menyenangkan akan tetapi juga membuat anak-anak makin tekun dan ulet dalam menghadapi kesulitan. ${ }^{21}$ Ulet sebagai mana yang disampaikan oleh emda tidak lain memiliki makna pantang menyerah.

Dampak selanjutnya adalah pembelajaran menjadi lebih efektif dan efisien. Berbeda dengan presentasi di depan kelas yang jumlahnya banyak, dengan metode jigsaw penyampaian materi secara mendalam dilakukan dengan presentasi oleh anak-anak pada kelompok asalnya masing-masing. Dengan demikian pembelajaran menjadi lebih efektif karena kelompok hanya berjumlah 45 anak saja. Penyampaian materi dapat dilakukan secara lebih eksklusif sehingga mudah diserap dan dipahami oleh anak-anak. Sebagaimana yang disebutkan oleh William yang dikutip oleh Retnowati dan Aqiilah, bahwasanya pembentukan kelompok kecil yang terdiri 4-5 orang akan lebih menimimalisir adanya social loafing. Social loafing dimaknai sebagai berkurangnya semangat dan motivasi seseorang karena adanya orang lain dalam kelompok. ${ }^{22}$ Artinya, kelompok kecil akan membuat siswa menjadi lebih fokus dalam berdiskusi karena lebih sedikit gangguan jika dibandingkan dengan jumlah anggota kelompk yang lebih banyak. Dengan demikian, penyampaian materi dengan kelompok belajar yang kecil jumlahnya cenderung lebih mudah diserap dan diingat oleh siswa daripada penyapampaian materi pada kelas dengan jumlah besar.

Dalam kaitannya dengan motivasi belajar tentunya dapat dilihat dengan hasil atau prestasi belajar yang meningkat. Karena apabila seorang peserta didik telah termotivasi untuk belajar maka ia akan selalu tertarik sehingga bisa meningkatkan

20 Ramli Abdullah, "Pengaruh Penerapan Model Pembelajaran Kooperatif Tipe Jigsaw Pada Mata Pelajaran Kimia Di Madrasah Aliyah," Lantanida journal 5, no. 1 (2017): 13-28.

${ }^{21}$ Emda, "Kedudukan Motivasi Belajar Siswa Dalam Pembelajaran."

22 Endah Retnowati, "Efektivitas Strategi Pengelompokan Berpasangan Dalam Pembelajaran Matematika Model Core," Jurnal Cakrawala Pendidikan 36, no. 1 (February 21, 2017), accessed January 31, 2022, http://journal.uny.ac.id/index.php/cp/article/view/12628. 
hasil belajarnya, baik secara akademik juga secara sosial emosional. ${ }^{23}$ Sebagaimana yang disampaikan oleh Winkel dan dikutip oleh Hamid pada penelitiannya bahwa motivasi belajar merupakan penggerak seseorang untuk belajar, dengannya ia akam memberikan arah pada kegiatan belajar sehingga tujuan belajar akan dapat tercapai. ${ }^{24}$ Dan tujuan tersebut tidak lain dan bukan adalah hasil belajar berupa prestasi siswa pada MTs The Noor Pacet, terbukti dengan semakin semangatnya peserta didik dalam kegiatan belajar dengan indikator tidak ada yang mengantuk dan semuanya aktif. Selain itu saat dilakukan evaluasi tertulis di akhir jam pelajaran, anak-anak bisa menjawab soal dengan cukup tepat.

Dengan demikian analisis penulis pada penelitian yang dilakukan adalah bahwasanya metode jigsaw mampu memberikan implikasi baik diantaranya adalah: 1) Mampu menumbuhkan dan meningkatkan semangat belajar peserta didik. 2) Mampu menumbuhkan jiwa pantang menyerah atau ulet, dan tanggung jawab. 3) Meningkatkan efektivitas pembelajaran. 4) Mampu meningkatkan hasil belajar peserta didik..

\section{Kesimpulan}

Metode jigsaw yang diterapkan pada pelajaran fikih pada MTs The Noor Pacet Mojokerto merupakan suatu langkah tepat dalam perancangan dan penerapan di pembelajaran. Melalui metode jigsaw ini motivasi belajar peserta didik mampu ditumbuhkan lebih besar lagi yang terwujud pada implikasiimplikasi positif sebagaimana yang telah dipaparkan sebelumnya. Dengan demikian metode jigsaw ini dapat menjadi salah satu acuan dalam metode pembelajaran yang layak diterapkan setiap instansi pendidikan.

\section{Daftar Pustaka}

Abdullah, Ramli. "Pengaruh Penerapan Model Pembelajaran Kooperatif Tipe Jigsaw Pada Mata Pelajaran Kimia Di Madrasah Aliyah." Lantanida journal 5, no. 1 (2017): 13-28.

Ciptaningsih, Yeni, and Muhammad Husnur Rofiq. "Participatory Learning With Game Method For Learning Completeness In Islamic Religious Education." Fikroh: Jurnal Pemikiran dan Pendidikan Islam 15, no. 1 (January 29, 2022): 1829.

23 Heriyono Heriyono et al., "Gaya Kepemimpinan Prof. Dr. Kh. Asep Saifuddin Chalim Dalam Meningkatkan Motivasi Kerja Karyawan Di Pesantren," Munaddhomah: Jurnal Manajemen Pendidikan Islam 2, no. 1 (August 3, 2021): 21-30; Maptuhah Maptuhah and Juhji Juhji, "Pengaruh Perhatian Orangtua Dalam Pembelajaran Daring Terhadap Motivasi Belajar Peserta Didik Madrasah Tsanawiyah," Attadrib: Jurnal Pendidikan Guru Madrasah Ibtidaiyah 4, no. 1 (May 22, 2021): 25-34.

24 Marwan Hamid, "Hubungan Antara Motivasi Dengan Prestasi Belajar Ekonomi Siswa Kelas VIII SMP Negeri 2 Jangka Kabupaten Bireuen," Lentera: Jurnal Ilmiah Sains dan Teknologi 13, no. 4 (2013): 147357. 
Emda, Amna. "Kedudukan Motivasi Belajar Siswa Dalam Pembelajaran." Lantanida Journal 5, no. 2 (2018): 172-182.

Hamid, Marwan. "Hubungan Antara Motivasi Dengan Prestasi Belajar Ekonomi Siswa Kelas VIII SMP Negeri 2 Jangka Kabupaten Bireuen." Lentera: Jurnal Ilmiah Sains dan Teknologi 13, no. 4 (2013): 147357.

Heriyono, Heriyono, Rudolf Chrysoekamto, Rezki Nurma Fitriah, and Ari Kartiko. "Gaya Kepemimpinan Prof. Dr. Kh. Asep Saifuddin Chalim Dalam Meningkatkan Motivasi Kerja Karyawan Di Pesantren." Munaddhomah: Jurnal Manajemen Pendidikan Islam 2, no. 1 (August 3, 2021): 21-30.

Hidayah, Siti Na'ilul, and Ashif Az-zafi. "The Role Of The Religious Laboratory In Improving Students 'Understanding Of Fiqh Lessons." Tafkir: Interdisciplinary Journal of Islamic Education 2, no. 2 (July 25, 2021): 157-174.

Huda, Ali Muhdlorul, and Mauhibur Rokhman. "The Strategy of the Principal in Improving the Quality of Institutional Education." Attadrib: Jurnal Pendidikan Guru Madrasah Ibtidaiyah 4, no. 2 (November 5, 2021): 72-80.

Khotimah, Husnul, Asep Supena, and Nandang Hidayat. "Meningkatkan attensi belajar siswa kelas awal melalui media visual." Jurnal Pendidikan Anak 8, no. 1 (August 21, 2019): 17-28.

Kusmaniar. "Peningkatan Motivasi Belajar Siswa Melalui Model Pembelajaran Kooperatif Tipe Jigsaw." FITRA 4, no. 1 (August 10, 2018). Accessed January 31, 2022. http://jurnal.staitapaktuan.ac.id/index.php/fitra/article/view/62.

Lubis, Nur Ainun, and Hasrul Harahap. "Pembelajaran Kooperatif Tipe Jigsaw | Jurnal As-Salam." Jurnal As-Salam 1, no. 1 (2016). Accessed January 31, 2022. https://jurnal-assalam.org/index.php/JAS/article/view/48.

Maptuhah, Maptuhah, and Juhji Juhji. "Pengaruh Perhatian Orangtua Dalam Pembelajaran Daring Terhadap Motivasi Belajar Peserta Didik Madrasah Tsanawiyah." Attadrib: Jurnal Pendidikan Guru Madrasah Ibtidaiyah 4, no. 1 (May 22, 2021): 25-34.

Mawardi, Mawardi. “Optimalisasi Kompetensi Guru Dalam Penyusunan Rencana Pelaksanaan Pembelajaran." JURNAL ILMIAH DIDAKTIKA: Media Ilmiah Pendidikan dan Pengajaran 20, no. 1 (August 1, 2019): 69-82.

Moleong, Lexy J. Metodologi penelitian kualitatif. Remadja Karya, 1989.

Muslimin, Tri Adi, and Ari Kartiko. "Pengaruh Sarana Dan Prasarana Terhadap Mutu Pendidikan Di Madrasah Bertaraf Internasional Nurul Ummah Pacet Mojokerto." Munaddhomah: Jurnal Manajemen Pendidikan Islam 1, no. 2 (2020): 75-87.

Pakpahan, Poetri Leharia, and Umi Habibah. "Manajemen Program Pengembangan Kurikulum PAI Dan Budi Pekerti Dalam Pembentukan Karakter Religius Siswa: Management of IRE Curriculum Development Program and Character in Forming Student's Religious Character." Tafkir: Interdisciplinary Journal of Islamic Education 2, no. 1 (January 10, 2021): 1-20.

Rahmat. Evaluasi Pembelajaran Pendidikan Agama Islam. Bening Pustaka, 2019. 
Ratih, Ratih, and Fauzi Muharom. "Tasamuh Based E-Module Developtment in The Fiqih Subject for 10th Grade Students in Islamic Senior High School." Nazhruna: Jurnal Pendidikan Islam 4, no. 3 (October 19, 2021): 531-546.

Retnowati, Endah. "Efektivitas Strategi Pengelompokan Berpasangan Dalam Pembelajaran Matematika Model Core." Jurnal Cakrawala Pendidikan 36, no. 1 (February 21, 2017). Accessed January 31, 2022. http://journal.uny.ac.id/index.php/cp/article/view/12628.

Rusman. Model-Model Pembelajaran Mengembangkan Profesionalisme Guru. Raja Grafindo Persada, 2016.

Sirojuddin, Akhmad, Andika Aprilianto, and Novela Elza Zahari. "Peran Kepala Sekolah Sebagai Supervisor Pendidikan Dalam Meningkatkan Profesionalisme Guru." Chalim Journal of Teaching and Learning (CJoTL) 1, no. 2 (2021): 159-168.

Sugiyono. Metode penelitian pendidikan: (pendekatan kuantitatif, kualitatif dan $R \mathcal{E} D$ ). Alfabeta, 2008.

Tajuddin, Muhtar, and Imam Syafi'i. "Blended Learning Model of Ulumul Hadith Through Whatsapp Media." Nazhruna: Jurnal Pendidikan Islam 4, no. 2 (June 12, 2021): 162-179.

Zaenudim, Zaenudin. "Meningkatkan Hasil Belajar Siswa Pada Mata Pelajaran Fiqh Melalui Penerapan Strategi Bingo." Edukasia: Jurnal Penelitian Pendidikan Islam 10, no. 2 (September 27, 2015). Accessed January 31, 2022. https://journal.iainkudus.ac.id/index.php/Edukasia/article/view/796.

Zulaikhah, Dinda, Akhmad Sirojuddin, and Andika Aprilianto. "Analisis Pembelajaran Pendidikan Agama Islam Kurikulum 2013 Bagi Anak Berkebutuhan Khusus." Tafkir: Interdisciplinary Journal of Islamic Education 1, no. 1 (2020): 54-71. 